\title{
PENYULUHAN PEMBERIAN PROBIOTIK BIOPLUS TERHADAP PERFORMA DOMBA DI KELOMPOK WANITA TANI SAUYUNAN
}

\section{Counseling of Bioplus Probiotics Supplementation on The Performance of Sheep In The Womens Farmer Group Sauyunan}

\author{
Mutia Sari, Kenedy Putra, dan Lilis Riyanti \\ Program Studi Penyuluhan Peternakan dan Kesejahteraan Hewan \\ Jurusan Peternakan Politeknik Pembangunan Pertanian Bogor \\ *Email: sarimutias14@gmail.com
}

\begin{abstract}
The population of sheep in Kaso Village, Tambaksari District is still very low compared to the average number of needs each year. One of the feed manipulation techniques that can be done is by giving Bioplus probiotics. This study aims to analyze the increase in knowledge and skills of farmers on the provision of Bioplus probiotics. This study aims to analyze the improvement of farmers' knowledge and skills on the provision of Bioplus probiotics The extension technique used uses a combination of media and extension methods such as lectures, discussions, demonstrations of methods, and applied studies and is combined with powerpoint media and posters. The instrument used is a questionnaire that has been tested for validity and reliability using SPSS version 21 . The counseling respondents consisted of 30 members of KWT Sauyunan. The evaluation of the extension was analyzed using the Padmowiharjo formula (1999). The results of the extension evaluation show the criteria of Success for the knowledge aspect and Fairly Successful in the skill aspect. Thus the extension of the provision of Bioplus probiotics to sheep is able to increase the knowledge and skills of members of the women's farmer group.
\end{abstract}

Keywords: bioplus, counseling, sheep, probiotics

\begin{abstract}
ABSTRAK
Populasi domba di Desa Kaso Kecamatan Tambaksari masih sangat kurang jika dibandingkan dengan jumlah kebutuhan rata-rata setiap tahuannya. Sehingga Teknik manipulasi pakan masih sangat dibutuhkan di daerah ini guna untuk meningkatkan produksi daging sapi. Salah satu teknik manipulasi pakan yang dapat dilakukan adalah dengan pemberian probiotik Bioplus. Penelitian ini bertujuan untuk menganalisis peningkatkan pengetahuan dan keterampilan peternak terhadap pemberian probiotik Bioplus. Teknik penyuluhan yang digunakan menggunakan gabungan antara media dan metode penyuluhan seperti ceramah, diskusi, demonstrasi cara dan kaji terap dan dipadukan dengan media power point dan poster. Teknik penelitian ini dengan menyebarkan kuesioner yang telah diuji validitas dan realibilitasnya menggunakan SPSS versi 21. Responden penyuluhan terdiri atas 30 anggota KWT Sauyunan. Evaluasi penyuluahan dianalisis menggunakan rumus Padmowiharjo (1999). Hasil evaluasi penyuluhan menunjukkan kriteria Berhasil untuk aspek pengetahuan dan Cukup Berhasil pada aspek keterampilan. Dengan demikian penyuluhan pemberian probiotik Bioplus pada ternak domba mampu meningkatkan pengetahuan dan keterampilan anggota kelompok wanita tani.
\end{abstract}

Kata Kunci: bioplus, domba, probiotik, penyuluhan 


\section{PENDAHULUAN}

Kecamatan Tambaksari memiliki potensi sumberdaya alam berupa lahan usaha baik untuk lahan kering maupun lahan basah. Banyaknya lahan kering yang belum tergarap perlu disikapi sebagai peluang untuk dimanfaatkan lebih optimal sehingga dapat memberikan daya dukung yang besar terhadap usaha peternakan khususnya domba. Komoditas peternakan yang ada di Kecamatan Tambaksari sangat beragam yaitu sapi potong, kerbau, kambing, domba, ayam ras, maupun ayam Buras. Dilihat dari populasi, ternak domba merupakan populasi terbanyak setelah kambing, yakni mencapai 4.822 ekor.

Beternak domba merupakan usaha yang sederhana namun menguntungkan. Modal yang dibutuhkan tidak begitu besar sehingga setiap orang dapat melakukan usaha ini pada kelas menengah ke atas. Hal ini ditandai dengan perputaran modal yang stabil dan cepat. Permintaan terhadap ternak domba cukup tinggi untuk konsumsi. Permintaan akan meningkat menjelang hari raya Idul Adha.

Berdasarkan hasil survei lokasi produktivitas ternak domba masih rendah. Hal ini diakibatkan upaya pemeliharaan dan metode penggemukan masih dilakukan secara konvensional. Makanan yang diberikan merupakan limbah pertanian yang tidak memenuhi syarat kualitas pakan ternak. Oleh karena itu, diperlukan upaya peningkatan mutu pakan ternak sehingga bisa meningkatkan bobot ternak dengan lebih signifikan. Salah satu upaya yaitu pemberian probiotik plus.

Probiotik merupakan feed supplement mikrob hidup yang di dalam tubuh menguntungkan induk semangnya. Probiotok bertujuan untuk membantu proses pencernaan khususnya serat kasar didalam rumen. Selain itu juga mengatur keseimbangan mikrob rumen dalam saluran pencernaan sehingga pakan lebih mudah dicerna dan diserap kedalam tubuh, pada akhirnya meningkatkan pertumbuhan bobot badan (Fuller 1992).

Probiotik memiliki sifat sebagai pemacu metabolisme dan meningkatkan proses pencernaan dalam rumen ternak. Selain itu juga dapat mengimbangi kemampuan pakan, terutama pakan berkualitas rendah (Winugroho et al 1993; Winugroho dan Marjati 2001). Kebutuhan nutrisi domba jantan dengan berat badan (BB) $20 \mathrm{~kg}$ yaitu bahan kering (BK) 33,6\%, protein kasar (PK) 11,8\%, TDN 65,0\%, kalsium $(\mathrm{Ca})$ 0,40\%, serta posfor $(\mathrm{P})$ 0,36\% (BPTP 2015).

Upaya untuk mengatasi berbagai permasalahan yang dihadapi oleh peternak terutama di daerah sentra penggemukan domba di Kabupaten Ciamis, Jawa Barat maka diperlukan penyebar luasan informasi mengenai pemberian probiotik Bioplus dan pakan tambahan. Menurut Schalbroeck (2001), pemberian probiotik bioplus pada domba dengan fungsi suplemen mikrob hidup yang di dalam tubuh dapat menguntungkan induk semangnya. Hal ini dikarenakan kinerja probiotik lebih banyak membantu proses pencernaan serat kasar.

\section{METODE PENELITIAN}

\section{Waktu dan Tempat}

Penelitian ini dilaksanakan bulan April 2021 sampai Juni 2021 di Kelompok Wanita Tani Sauyunan, Desa Kaso, Kecamatan Tambaksari, Kabupaten Ciamis, Jawa Barat.

\section{Materi dan Metode}

Dalam penelitian ini disampaikan materi berupa pengenalan dan penerapan penggunaan probiotik bioplus sebagai pakan tambahan ternak domba untuk meningkatkan pertumbuhan bobot badan sehingga diharapkan dapat meningkatkan pendapatan peternak. Selain pengenalan dan penerapan penggunaan probiotik bioplus, dilakukan juga penyuluhan yang 
berisi materi penyuluhan menyesuaikan masalah dan kebutuhan di KWT.

Penyuluhan dilakukan dengan menggunakan metode kaji terap, ceramah, anjangsana, dan diskusi sesuai kebutuhan dan permintaan peternak. Penyuluhan ini mengunakan media power point dan poster, karena dianggap sesuai dengan keadaan lokasi penyuluhan.

\section{Instrumen}

Teknik pengumpulan data yang dilakukan untuk mengukur tingkat pengetahuan dan keterampilan peternak responden tentang pemberian probiotik adalah dengan meyebarkan kuesioner. Dimana sebelumnya sudah dilakukan uji validitas dan reliabilitas.

Uji validitas kuesioner dilaksanakan dengan membagikan kuesioner kepada peternak yang bukan merupakan sampel responden, dalam upaya peternak mengetahui dalam uji probiotik sebelum melakukan uji terdapat pengumpulan dan analisis data menggunakan SPSS versi 21 serta aplikasi Microsoft Excel.

\section{Uji Validitas}

Validitas menurut Sugiyono (2017) berfungsi untuk ketepatan instrumen dalam mengukur kondisi atau data aktual. Pengujian ini menggunakan perangkat lunak Statistical Product and Service Solution (SPSS) versi 21. Menurut Sugiyono (2017) bahwa valid berarti kinerja instrumen dalam pengukuran sudah tepat. Valid ditunjukkan dengan derajat ketepatan hasil penelitian dengan kondisi yang sebenarnya di lapangan.

\section{Uji Reliabiltas}

Uji reliabiltas instrumen penelitian menggunakan Cronbach's Alpha yang dianalisis dengan SPSS versi 21. Pada penelitian, instrument dinyatakan reliabel jika nilai Cronbach's Alpha > 0,70. Cronbach's Alpha dapat diinterpretasikan sebagai hubungan antara skala yang diamati dengan skala lain pada saat mengukur butir pertanyaan yang sama. Hasil pengujian ditunjukkan dengan output SPSS yang menunjukkan nilai Cronbach's Alpha dari keseluruhan butir pertanyaan pada instrument penelitian. Instrument dikatakan memiliki reliabilitas yang tinggi jika nilai Cronbach's Alpha > 0.7 (Ratnaningsih 2010).

\section{Pengumpulan dan Analisis Data}

Beberapa jenis data yang dikumpulkan dalam penelitian ini adalah : 1) data hasil uji validitas dan reliabilitas instrumen, diperoleh dari intrumen yang dibagikan dan ditabulasikan ke dalam Microsoft excel kemudian dianalisis menggunakan SPSS; dan 2) data hasil evaluasi pre test dan post test tingkat pengetahuan dan keterampilan peternak Uji validitas dan reliabilitas dianalisis menggunakan SPSS versi 21. Aspek penyuluhan (kuesioner pre test dan post test) untuk mengetahui tingkat perubahan pengetahuan dan keterampilan petani sebelum dan setelah penyuluhan terkait pemberian probiotik bioplus pada budidaya ternak domba. Analisis tersebut menggunakan rumus sebagai berikut:

Tingkat pengetahuan
$=\frac{\text { Skor yang diperoleh }}{\text { Nilai Maksimal }} \times 100$

Tingkat keterampilan

$=\frac{\text { Skor yang diperoleh }}{\text { Nilai Maksimal }} \times 100$

Menurut Padmowihardjo (1999) untuk mengetahui tingkat keberhasilan penyuluhan dapat dihitung menggunakan rumus:

$\mathrm{N} \%=\frac{\left(\sum \text { nilai post test }-\sum \text { nilai pre test }\right)}{\mathrm{NM}} \times 100$

Keterangan:

$\mathrm{N} \%=$ Persentase hasil

Nilai pre test $\quad=$ Nilai awal 
Nilai post test $\quad=$ Nilai akhir

$\mathrm{NM}$ (nilai maksimal) = Nilai tertinggi $\mathrm{x}$ jumlah pertanyaan $x$ jumlah responden

Tingkat keberhasilan penyuluhan diukur dengan menggunakan kriteria sebagai berikut:
$0-25 \%$
$=$ Kurang Berhasil
$26-50 \%$
$=$ Cukup Berhasil
$51-75 \%$
$=$ Berhasil
$76-100 \%$
= Sangat Berhasil

\section{HASIL DAN PEMBAHASAN}

\section{Uji Validitas}

Pengujian validitas instrument dilakukan pada 30 orang responden di kelompok berbeda yang memiliki karakteristik yang sama dengan Kelompok Wanita Tani (KWT) Sauyunan. Berdasarkan hasil pengujian validitas dengan aplikasi SPSS versi 21 diperoleh hasil yaitu 15 dari 20 soal dinyatakan valid. Dengan ini menunjukkan bahwa hasil pengujian yang menunjukkan butir-butir pertanyaan dari kuesioner yang nilainya diatas nilai $r$ tabel yaitu $>0,361$ dengan taraf signifikansi $5 \%$.

\section{Uji Reliabilitas}

Pengujian reliabilitas menggunakan metode Alpha Cronbach's skala yang reliabel memiliki nilai Alpha Cronbach's > 0,7 (Ratnaningsih 2010). Berdasarkan hasil pengujian menggunakan SPSS versi 21 nilai Cronbach's Alpha dari hasil jawaban sampel peternak sebesar 0,863. Dapat disimpulkan bahwa butir pertanyaan pada penelitian ini reliabel $>0,7$.

\section{Evaluasi Penyuluhan}

Pada pengukuran pengetahuan dan keterampilan peternak dalam penggunaan probiotik Bioplus maka dilakukan evaluasi penyuluhan. Dari data rekapitulasi evaluasi awal (pre test) dapat diketahui tingkat pengetahuan dan keterampilan peternak Kelompok Wanita Tani (KWT) Sauyunan sebelum diberikan penyuluhan. Hasil pre test tingkat pengetahuan dan keterampilan petani dapat dilihat pada Tabel 1.

Tabel 1 Hasil Pre Test Tingkat Pengetahuan dan Keterampilan

\begin{tabular}{llccc}
\hline \multicolumn{2}{c}{ Aspek yang dinilai } & & \multicolumn{3}{c}{ Pre test } \\
\cline { 3 - 5 } & & $\begin{array}{c}\text { Jumlah } \\
\text { Nilai }\end{array}$ & $\begin{array}{c}\text { Jumlah } \\
\text { nilai max }\end{array}$ & $\begin{array}{c}\text { Persentase } \\
\text { (\%) }\end{array}$ \\
\hline $\begin{array}{l}\text { Pengetahuan pemberian probiotik } \\
\text { terhadap performa domba }\end{array}$ & 538 & 1350 & 39,85 \\
$\begin{array}{l}\text { Keterampilan pemberian probiotik } \\
\text { terhadap performa domba }\end{array}$ & Bioplus & 324 & 900 & 36 \\
\hline
\end{tabular}

Sumber : Data primer diolah 2021

Evaluasi akhir (post test) dilaksanakan pada penyuluhan terakhir dengan tujuan untuk mengetahui perubahan pengetahuan dan keterampilan peternak setelah diadakan penyuluhan tentang pemberian probiotik bioplus pada domba, di tahapan ini dapat di lihat apakah pengetahuan dan ketarmpilan peternak semakin bertambah atau mungkin sebaliknya tidak ada perubahan sama sekali, Data rekapitulasi dari evaluasi akhir (post test) tingkat pengetahuan dan keterampilan peternak di Kelompok Wanita Tani (KWT) Sauyunan setelah diberikan penyuluhan tahap akhir dapat dilihat pada Tabel 2 dibawah ini. 
Tabel 2 Hasil Post Test Tingkat Pengetahuan dan Keterampilan

\begin{tabular}{lcrc}
\hline \multicolumn{1}{c}{ Aspek yang dinilai } & \multicolumn{3}{c}{ Post test } \\
\cline { 2 - 4 } & Jumlah Nilai & $\begin{array}{c}\text { Jumlah } \\
\text { nilai max }\end{array}$ & $\begin{array}{l}\text { Persentase } \\
\text { (\%) }\end{array}$ \\
\hline $\begin{array}{l}\text { Pengetahuan pemberian probiotik } \\
\text { bioplus terhadap performa domba } \\
\begin{array}{l}\text { Keterampilan pemberian probiotik } \\
\text { Bioplus terhadap performa domba }\end{array}\end{array}$ & 1231 & 1350 & 91,19 \\
\hline
\end{tabular}

Sumber : Data diolah 2021

Tabel 1 dan 2 menunjukkan adanya peningkatan pengetahuan dan keterampilan peternak dalam pemberian probiotik Bioplus untuk meningkatkan bobot badan domba. Nilai awal pengetahuan peternak sebelum penyuluhan sebesar 538 dengan persentase $\quad 39,85 \%$. Setelah pelaksanaan penyuluhan nilai pengetahuan peternak meningkat menjadi 1231 dengan persentase
91,19\%. Kemudian nilai awal keterampilan peternak sebelum dilakukan penyuluhan sebesar 324 (36\%). Setelah pelaksanaan penyuluhan nilai keterampilan peternak meningkat menjadi 763 (84,78\%). Keberhasilan penyuluhan berdasarkan aspek pengetahuan dan keterampilan didapatkan setelah dilakukan evaluasi awal dan evaluasi akhir. Hasil evaluasi pada Tabel 3.

Tabel 3 Keberhasilan Penyuluhan Berdasarkan Aspek Pengetahuan dan Keterampilan

\begin{tabular}{|c|c|c|c|c|c|c|c|}
\hline \multirow{2}{*}{$\begin{array}{l}\text { Aspek } \\
\text { yang } \\
\text { dinilai }\end{array}$} & \multicolumn{2}{|c|}{$\begin{array}{c}\text { Jumlah } \\
\text { Nilai }\end{array}$} & \multirow{2}{*}{$\begin{array}{l}\text { Jumlah } \\
\text { nilai } \\
\text { maksimal }\end{array}$} & \multirow{2}{*}{$\begin{array}{l}\text { Pre } \\
\text { test } \\
(\%)\end{array}$} & \multirow{2}{*}{$\begin{array}{l}\text { Post } \\
\text { test } \\
(\%)\end{array}$} & \multirow{2}{*}{$\begin{array}{l}\text { Keberhasilan } \\
\text { penyuluhan } \\
\text { (\%) }\end{array}$} & \multirow[t]{2}{*}{ Kriteria } \\
\hline & $\begin{array}{l}\text { pre } \\
\text { test }\end{array}$ & $\begin{array}{l}\text { Post } \\
\text { test }\end{array}$ & & & & & \\
\hline Pengetahuan & 538 & 1231 & 1350 & 39,85 & 91,19 & 51,34 & Berhasil \\
\hline Keterampilan & 324 & 763 & 900 & 36 & 84,78 & 48,78 & $\begin{array}{l}\text { Cukup } \\
\text { Berhasil }\end{array}$ \\
\hline
\end{tabular}

Sumber : Data diolah 2021

Tabel 3 menunjukkan bahwa sebelum dilakukannya penyuluhan (pre test), skor dari aspek pengetahuan yang diperoleh dari 30 responden adalah 538 $(39,86 \%)$. Berdasarkan hasil tersebut dilakukan penyuluhan hingga didapatkan peningkatan skor aspek pengetahuan peternak menjadi 1231 $(91,19 \%)$ (post test). Sama halnya dengan aspek keterampilan yakni nilai yang diperoleh sebelum dilakukannya penyuluhan (pre test) adalah 324 (36\%) hingga didapatkan peningkatan skor aspek keterampilan peternak menjadi 763 (84,78\%) (post test). Analisis secara keseluruhan menunjukkan hasil yang sangat baik. Pengetahuan dan keterampilan yang dimiliki peternak mengalami peningkatan.

Berdasarkan

Tabel 3

menjelaskan terdapat selisih antara pre test dan post test aspek pengetahuan sebesar $51,34 \%$ sehingga berdasarkan aspek tingkat pengetahuan dinyatakan bahwa kegiatan penyuluhan yang dilakukan di KWT Sauyunan 
memperoleh Kriteria Berhasil. Kemudian terdapat selisih antara pre test dan post test aspek keterampilan sebesar $48,78 \%$ sehingga berdasarkan aspek tingkat keterampilan dinyatakan bahwa kegiatan penyuluhan yang dilakukan di KWT Sauyunan memperoleh kriteria cukup berhasil. Ban, A.W. van den dan H.S. Hawkins (1999) menyatakan bahwasanya persepsi penerima terhadap suatu inovasi ditinjau dari karakteristik inovasi teknologi tersebut. Karakteristik inovasi yang dapat mendukung persepsi petani meliputi keunggulan relatif, tingkat kesesuaian, tingkat kerumitan, kemudahan untuk dicoba dan kemudahan untuk diamati (Rogers 2005).

Menurut Nurcahyo et al. (2017), faktor kekuatan peternak domba meliputi internal dan eksternal. Pada faktor internal seperti kemauan untuk menigkatkan ilmu dan pengetahuan sepanjang hayat, memiliki motivasi untuk memberikan yang terbaik bagi hewan ternaknya, mampu bekerjasama dan bekerja keras serta mau meningkatkan kompetensi tentang implementasi teknologi untuk meningkatkan produktivitas ternak. Menurut Arikunto (1999), peningkatan kapasitas petani bisa dicapai dengan dukungan stakeholders melalui penyuluhan dan demonstrasi.

\section{SIMPULAN DAN SARAN}

\section{Simpulan}

Evaluasi penyuluhan peternakan terkait penggunaan probiotik Bioplus menunjukkan terdapat peningkatan pengetahuan dan keterampilan peternak setelah dilakukan penyuluhan sehingga penyuluhan dikategorikan telah berhasil. $\mathrm{Hal}$ ini ditandai dengan peningkatan nilai pengetahuan mencapai $51,34 \%$ serta adannya peningkatan keterampilan mencapai $48,78 \%$.

\section{Saran}

Bagi peternak tetap semangat mengakses informasi baru yang dapat diterapkan. Penggunaan probiotik Bioplus dapat menjadi rekomendasi bagi peternak untuk meningkatkan bobot badan domba, sehingga dapat dijadikan pertimbangan bagi peternak untuk diterapkan.

\section{DAFTAR PUSTAKA}

[BPTP] Balai Pengkajian Teknologi Pertanian. 2015. Manajemen pemeliharaan ternak domba. Petunjuk Teknis. Bandung: BPTP Jawa Barat.

Arikunto S. 1999. Strategi pembelajaran muatan lokal. Lokakarya kajian muatan lokal bagi guru sekolah dasar. Diselenggarakan Dinas Pendidikan dan kebudayaan Prop. DIY bekerjasama dengan Puslit Dikdasmen Lembaga penelitian Yogyakarta

Ban, AW Van Den, Dan HS, Hawkins. 1999. Penyuluhan pertanian. Kanisius. Yogyakarta.

Fuller R. 1992. Probiotics the science basis. Chapman and Hall, London. New York. Tokyo. Melbourne: Madras.pp. 1-7.

Nurcahyo $\mathrm{H}$, Ciptono, Harjana $\mathrm{T}$, Hasanah H. 2017. Peningkatan produktivitas ternak domba dengan penerapan mineral komplit secara terprogram di keputren bleret, Bantul. Jurnal Pengabdian Masyarakat MIPA dan Pendidikan MIPA. 1 (1): 6-11.

Padmowihardjo S. 1999. Media penyuluhan pertanian. Jakarta: Universitas Terbuka.

Ratnaningsih D. 2010. Metode penelitian. Jakarta: Media Pustaka.

Rogers. 2005. Software Engineering: Apracticioner's Approach 6th Edition. New York. McGraw-Hill.

Schalbroeck. 2001. Toxicologikal evolution of red mold rice. Bogor: Fakultas Peternakan Institut Pertanian Bogor.

Sugiyono. 2017. Metode penelitian 
kuantitatif, kualitatif, dan R\&D.

Bandung: Alfabeta, CV.

Winugroho $M$, Sabrani $M$, dan Punarbowo P. Non-genetik approach for selecting rumen fluid containing specific microorganisms

(Balitnak Method). IImu dan

Peternakan, (6)2: 5 - 9 . 